\title{
Export Diversification of Nepal: Policy Context and Impacts
}

\author{
Raj Kumar KC * \\ rajkhatry2005@gmail.com
}

\begin{abstract}
This study aims at examining the extent of diversification attained in trade relationships of Nepal, identify factors responsible for the situation and come out at suggestive package to foster more sustainable and contributing trading relationships to maximize the benefits for the country.

Studies have revealed that insufficient export diversification has virtually dragged the economy in total disarray due to defect in government policies. The developed world relies heavily on the exchange of goods and services for faster and sustainable economic progress. Trade has been a priority from the very beginning of the First Five- Year Plan in 1956, but it has failed to move ahead owing to lack of technology, appropriate policy measures and sufficient priority given to it.

The secondary analysis showed that the volume of trade has been continuously increasing with economic liberalization in the aftermath of 1990. However, the volume of exports has remained too meager to sustain Nepal's imports. Therefore, the volume of trade deficit is ever widening. Reforms to expedite exports that began in the late seventies have failed to yield a positive outcome in the national economy.

The liberalization of eighties, nineties and membership of World Trade Organization (WTO) have failed to ensure a sustained diversified trading structure both in terms of products and services and trading partners. Growing dependency on India has been one of the major challenges in the economy.
\end{abstract}

Keywords: Trade, Diversification, Comparative advantage, Competitive advantage, Exports

\section{Background}

If trade is the engine of economic growth, there are multiple factors that affect trade. One of the most important components affecting import and export phenomenon is the policy. No country can expect to achieve economic prosperity without selling its product to other countries.

However, Nepal's exports are heavily concentrated - both in terms of product and destination. Total exports to India would have been even more staggering if informal trade across the

* Faculty at Nepal Open University (NOU) and associated with Shanker Dev Campus, Tribhuvan University. This paper was presented in the First Global International Conference held in Kathmandu on December 13-14, 2019. 
Export Diversification of Nepal: Policy Context and Impacts

porous Nepal- India border had been documented (Sthapit, 2016). This concentration of trade has made Nepal's trade virtually dependent with India.

Trade in general, and export diversification and competitiveness in particular, are important for least-developed countries (LDCs) like Nepal for a number of reasons (Pant and Pant, 2009). However, macro-economic policies particularly trade policy, taxation policy, policies on tariff and non- tariff barriers, logistics and availability of resources always play a vital role in expediting trade diversification (both import and export trade).

Considering Nepal's involvement in bilateral, regional and multilateral trade agreements, (Pant and Pant, 2009), it has not been able to expedite export diversification and gain competiveness. Trade diversification is not the concern of developed countries alone, even developing and least developed countries have accorded equal priority to both import and export diversification.

According to Dutta, Mihov and Zandt (2008) South Korea during the 1970s was a net importer of non-electrical machinery, with imports in this sector exceeding 15 percent of total manufacturing imports while exports being less than two percent of total exports. In the same year, the US was a net exporter of machines in this category. However, by 1999, South Korea had become a leading exporter of machinery while the US became a net importer in this category. Over the same period of time, the industrial structure as well as the trade structure of South Korea changed rapidly. There was significant relocation of capital and labor across sectors and more importantly, a parallel process of diversification of output and exports. Over the past 20 years, this process of diversification was accompanied by a fivefold increase in South Korea's income per capita.

As far as Nepal's case is concerned, Nepal used to export jute, rice, handicrafts and agricultural products until the decade of 1970 s, but owing to mainly trade policy and other policies affecting Nepal's export was heavily suffered. Policy issues relating to trade, industry, interest rate, exchange rate and taxation can be blamed for poor diversification (Bajracharya, Manandhar and Bajracharya, 2019).

Business persons and governments all over the world are very serious about the severe results of currency appreciation and depreciation on different things such as imports, exports, domestic products, etc. A number of researches in this sector have been conducted in order to find out the impact of currency fluctuations on the import and export of the country as well.

A number of research works have concluded that G-7 countries' exports and imports took the effect due to currency fluctuations during the period of 1982-1999. Depreciation in exchange rate increases the domestic currency value and decreases the value of our own currency as well (Adhikari D, 2014).

Singapore, the United Arab Emirates (UAE) along with other Middle East and East Asian countries are the examples of achieving economic prosperity through trade.

To understand the possible impact of the melting of the currencies of eleven countries into one European currency, it is said that the impact on the different functions of money need to be explored. Money is basically being used to facilitate trading transactions (it's a lot easier than bartering), to store value, but a currency serves as an underlying value to given other currency trust and value too. This function used to be primarily fulfilled by gold. But now central banks

NJMSR V. 3 Issue $2(2019) 129$ 
prefer the currency of another country's central bank.

According to Adhikari, (2018) Nepal has been following a pegged exchange rate system with Indian rupee (INR) with periodic exchange rate corrections through revaluation or devaluation in the past. Nepal adopted different kind of exchange rate system for convertible currencies. In line with the economic liberalization policy followed since the mid-1980s, Nepal introduced current account convertibility in 1993, effectively pegging the Nepalese rupee (NPR) with INR at NPR 160 for INR 100, at the rate which was also set in 1960 when exchange rate with INR was pegged for the first time. Since 1993, exchange rate of NPR with other convertible currencies has been market-determined in line with the exchange rate of INR with convertible currencies.

Similarly, there has been an argument (Pant and Pant, 2009) that changes in the rate of foreign exchange not necessarily impact the export diversification in Nepal's context. However, studies carried out by NRB (2005 - 2016) show that change in foreign exchange rate has affected both import and export diversification.

Nepal pursued the open economic policies since the mid-1980s and further impetus was given with the enactment of various legislations including Privatization Act, Industrial Enterprise Act, Foreign Investment and Technology Transfer Act, Industrial Policy and Trade Policy, among other. Nepal joined the world trade bandwagon acceded to the World Trade Organization (WTO) and also become the member of two regional trading blocs in 2004 (Acharya, 2019)

Ever widening trade deficit is an undeniable fact of the Nepalese economy. Along with export capacity, international competitiveness in terms of quality export items, frictionless channels of delivery, real exchange rate, price stability, GDP and interest rate are also crucial determinants of trade balance. In the world of quota-free trade and ever decreasing tariff barriers, maintaining an appropriate exchange rate to reduce the widening gap between import and export is important (Adhikari, 2018).

\subsection{Statement of the Problem}

Nepal is an agro-based country having comparative advantages in agricultural products. The contribution of agriculture to the GDP is more than 40 percent. The industrial products are not enough to meet the domestic demands and the industrialization is still at infant stage. Despite being the members of the World Trade Organization (WTO), Nepal has not been able to reap any benefits from exports so far. This is mainly due to lack of focus on expediting exports. Trade policy along with other macro-economic policies is not export friendly (Sharma, 1999).

Policy plays a vital role to accelerate trade diversification. Policy here includes not only trade policy (export and import), but also indicates other policies such as monetary policy, tax policy and others.

Countries initially classified as rich countries were substantially more diversified than poor countries in their exports in 1962 and remained so until about 1990. From 1990 onwards, the growth-miracle countries had largely caught up in terms of their export diversification index (Dutta et al., 2008). 
Export Diversification of Nepal: Policy Context and Impacts

In comparison to the export trade, import trade has been more diversified. The position of balance of trade is weak. The government policy on trade diversification has less emphasis on export diversification. The volume of foreign trade has increased considerably, but the overall the situation of balance of payment is perennially negative owing to decline in export and increase of exports (Sharma, 1999).

According to Regmi (2010), trade policy contributes obliquely to overall growth performance of a country through promoting through efficient allocation of existing resources, specialization and consumption gains, attracting foreign direct investment (FDI) an accelerated accumulation of physical and human capital, enhanced technological transmissions, forward and backward linkages of export sectors, improvements in X- efficiency, economies of scale and existence of externalities (spillovers). Trade Policy has had an impact on the growth rate of output from the point of views of growth theories too.

Policies play a vital role in reaping benefits from trade. Apart from macro- economic policies that incorporate trade policy has had a significant impact on trade diversification.

Assertion of Sharma (1999), Dutta et al. (2008) and Regmi (2010) further emphasized the importance of macro-economic policy which largely determines the diversification of trade. It is because macroeconomic policies such as export-import policies, tax policies, policy relating to tariff and non- tariff barriers play a vital role in trade. There are many examples across the world as how the government policy affects export and import trade. Russia in 2014 had suffered a huge loss in export of dairy products and fruits to European countries owing to Russia's intervention in Ukraine. Similarly, China suffered a huge set back in export of readymade garments to the USA owing to the trade war between two countries (Bhurtel, 2017).

Hence, trade policy has been taken as one of the major determinants for the diversification of trade. Trade policy as one of the components of macroeconomic policies will be taken as an independent variable for the study.

Apart from macroeconomic policy, the other contributing factors that are highly likely to affect trade diversification are - inflation, exchange rate, availability of financial services, wage rate, interest rates and quality of goods, logistics, infrastructure, price of oil and trade union (UNCTAD, 2013)

Based on the available literature and realizing the need for conducting study in the changed political context, macroeconomic policies with special focus on trade policy and tax policy will be taken as independent variables. It is the macroeconomic policy that determines the trade diversification. Furthermore, trade policy in the context of federal system will have more importance.

\section{Review of Literature}

Trade is an indispensable component of an economy. In the 'Wealth of Nations', Adam Smith ridiculed the fear of trade by comparing nations to households. Smith argued that as every household could find it worthwhile to produce only some of its needs and to buy others, the same should apply to nations.

NJMSR V. 3 Issue 2(2019) 131 
Export Diversification of Nepal: Policy Context and Impacts

If a foreign country can supply us with a commodity cheaper than we ourselves can make it, better buy it of them with some part of the produce of our own industry, employed in a way in which we have some advantage' (Cannan E; ed. 2003).

Ricardo further argued that a nation could gain from foreign trade and specialization in products with comparative advantage (Ed Piero Staffa; 1951). The neo-classical and mainstream modern economists further modified and strengthened the idea of specialization. Heckscher-Ohlin ( $\mathrm{H}-\mathrm{O})$, the architect of modern theory of international trade, suggests that countries' export products use their abundant factors intensively.

"Commodities requiring for their production much of [abundant factors of production] and little of [scarce factors] are exported in exchange for goods that call for factors in the opposite proportions. Thus indirectly, factors in abundant supply are exported and factors in scanty supply are imported" (Ohlin; 1933, as quoted by Kindleberger; 1987).

\subsection{Impact of macroeconomic policies on export diversification}

The idea that export diversification contributes to an acceleration of growth in developing countries is a recurrent idea in development economics. In theory there are a number of channels through which export diversification might positively affect growth. By increasing the number of export sectors, horizontal export diversification can reduce the dependence on a limited number of commodities that are subject to extreme price and volume fluctuations (Herzer and Lheman, 2006).

Regmi, U.R (2010) states that trade policy contributes obliquely to overall growth performance of a country through promoting through efficient allocation of existing resources, specialization and consumption gains, attracting foreign direct investment (FDI) an accelerated accumulation of physical and human capital, enhanced technological transmissions, forward and backward linkages of export sectors, improvements in X- efficiency, economies of scale and existence of externalities (spillovers). Trade Policy has had an impact on the growth rate of output from the point of views of growth theories too.

However, Pant, B (2009) states that Nepal's policy regime has not been very instrumental in improving trade competitiveness. Although policy measures have been announced from time to time to identify new exportable products and encourage diversification of export markets, these have hardly been executed. The challenge for Nepal is complicated by the legacy of the past. Hence, export diversification has been proposed in the literature and in the policy debate as a key development strategy for developing countries. Most of the contributions, however, acknowledge that giving factual content to this diversification strategy is not easy. Policies play a vital role in reaping benefits from trade. Apart from macroeconomic policies that incorporate trade policy has had a significant impact on trade diversification.

Based on the opinions of Piazza Sdralevich (2004), Pant and Pant (2009), Regmi, U (2010), Sharma (1999) policy plays a vital role in determining trade diversification. Despite the changes in policies, Nepal has not been able to expedite export. There are couples of reasons behind poor diversification of export trade. One of the major components are trade policies, tax policies, tariff barriers and non-tariff barriers. Apart from these policy issues there are other macroeconomic components including monetary policy, interest rate policies and availability of resources. 
Export Diversification of Nepal: Policy Context and Impacts

\subsection{Conceptual Framework}

Based on the literature, we can draw a framework that the magnitude of trade diversification which includes both export and import (mainly export trade) largely depends on policy issues specially trade policy and tax policy which are taken as independent variables of trade diversification.

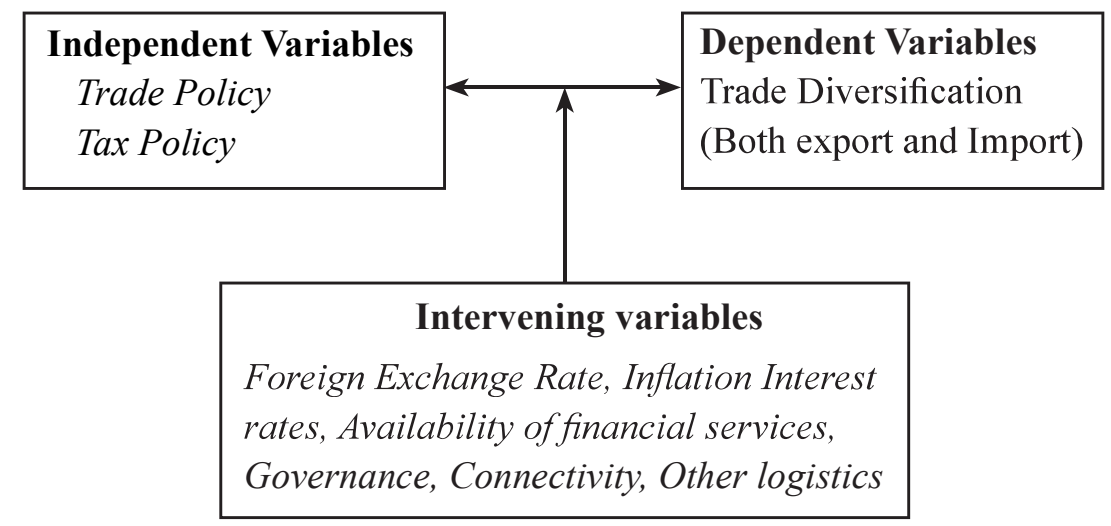

The study assumes that export diversification as the dependent variable whereas macroeconomic variables such as trade policy, tax policy, policies on tariff - non- tariff barriers shall be taken as independent variables. It is assumed that any changes in macroeconomic variables would impact export diversification. But at the same time, changes in diversification will also impact macroeconomic variables. On the other hand, foreign exchange rate, inflation, interest rates shall be taken as intervening variables.

\section{Methodology}

Some statistical instruments have been adopted to attain the research design with a time-series data and coverage and selection process, data collection and the nature of sources of data. Analysis procedures and the test statistics will be used in the study. The study is based on the secondary data.

\section{Current and Constant Prices}

While converting the data series of current price (obtained from various issues of Economic Survey, NRB and TEPC), the price 1974 (the data series from 1974/75 to 1983/84 was converted into 1984/85) price by using deflator and again converted to $1994 / 95$ and ultimately to $2000 / 01$ by using GDP deflator.

Hence, the all the data series were converted into the constant price $(100=2000$ AD) by using GDP deflator. The GDP deflator was calculated by dividing the price of the base year by the years and multiplied by 100 .

For instance, the current price of 2000 was converted into constant price by dividing the current price of 2000 by the price of base year and multiplied by 100 . Hence, the constant price of 1972 came to 9.99 . Similarly, the constant price of 2000 is 100 and 2005 is 126.83 (based on the GDP Deflator $2000=100$ ). 
Export Diversification of Nepal: Policy Context and Impacts

Table 1

Growth Trend of Foreign Trade of Nepal (Rs in Million)

\begin{tabular}{rrrrrrrr}
\hline Year & Exports & $\begin{array}{c}\text { Export } \\
\text { Growth } \\
\text { Rate } \\
\text { \% }\end{array}$ & Imports & $\begin{array}{c}\text { Imports } \\
\text { Growth } \\
\text { Rate \% }\end{array}$ & $\begin{array}{c}\text { Trade Bal- } \\
\text { ance }\end{array}$ & Total Trade & $\begin{array}{c}\text { Total } \\
\text { Trade } \\
\text { Growth } \\
\text { Rate \% }\end{array}$ \\
\hline $1975 / 76$ & 1185.80 & --- & $1,981.7$ & ----- & $(795.90)$ & 3167.50 & ----- \\
$1980 / 81$ & 1608.70 & 35.66 & $4,428.2$ & 123.45 & $(2819.50)$ & 6036.90 & 90.59 \\
$1985 / 86$ & 3078.00 & 91.33 & $9,341.2$ & 110.95 & $(6263.20)$ & 12419.20 & 105.72 \\
$1990 / 91$ & 7387.50 & 140.01 & $23,226.5$ & 148.65 & $(15839.00)$ & 30614.00 & 146.51 \\
$1995 / 96$ & 19881.10 & 169.12 & $74,454.5$ & 220.56 & $(54573.40)$ & 94335.60 & 208.15 \\
$2000 / 01$ & 55654.10 & 179.93 & $115,687.2$ & 55.38 & $(60,033.10)$ & $171,341.30$ & 81.63 \\
$2005 / 06$ & $60,234.10$ & 8.23 & $173,780.30$ & 50.22 & $(113,546.20)$ & $234,014.40$ & 36.58 \\
$2010 / 11$ & $64,338.50$ & 6.81 & $396,175.50$ & 127.97 & $(331,837.00)$ & $460,514.00$ & 96.79 \\
$2011 / 12$ & $74,261.00$ & 15.42 & $461,667.70$ & 16.53 & $(387,406.70)$ & $535,928.70$ & 16.38 \\
$2012 / 13$ & $76,917.17$ & 3.58 & $556,740.30$ & 20.59 & $(479,823.20)$ & $633,657.30$ & 18.24 \\
$2013 / 14$ & $91,991.40$ & 19.60 & $714,365.80$ & 28.31 & $(622,374.40)$ & $806,357.20$ & 27.25 \\
$2014 / 15$ & 85319.10 & -7.25 & $774,684.20$ & 8.44 & $(689,365.10)$ & $860,003.30$ & 6.25 \\
$2015 / 16$ & $70,117.10$ & -17.82 & $773,599.10$ & -0.14 & $(703,482.00)$ & $843,716.30$ & -1.89 \\
$2016 / 17$ & $73,049.10$ & 4.18 & $990,113.20$ & 27.99 & $(917,064.10)$ & $1063,162.30$ & 26.01 \\
\hline
\end{tabular}

Source- Economic Survey 201617

Table 2

Direction of Nepal's Foreign Trade (Amount in Million)

\begin{tabular}{lrrrrr}
\hline \multicolumn{1}{c}{ Description } & $\mathbf{2 0 1 1 / 1 2}$ & $\mathbf{2 0 1 2} / \mathbf{1 3}$ & $\mathbf{2 0 1 3} / \mathbf{1 4}$ & $\mathbf{2 0 1 4} / \mathbf{1 5}$ & $\mathbf{2 0 1 5} / \mathbf{1 6}$ \\
\hline Export & $\mathbf{7 4 , 2 6 1 . 0 0}$ & $\mathbf{7 6 , 9 7 1 . 0 0}$ & $\mathbf{9 1 , 9 9 1 . 0 0}$ & $\mathbf{8 5 , 3 1 9 . 1 0}$ & $\mathbf{7 0 , 1 1 7 . 0 0}$ \\
India & $49,616.30$ & $51,000.00$ & $59,614.00$ & $55,864.60$ & $39,494.00$ \\
China & ----- & $2,086.00$ & 2841.00 & $2,230.00$ & 1682.00 \\
Other countries & $24,644.70$ & $23,832.00$ & $29,537.00$ & $27,225.00$ & $28,942.00$ \\
Import & $\mathbf{4 6 1 , 6 6 7 . 7 0}$ & $\mathbf{5 5 6 , 7 4 0 . 0 0}$ & $\mathbf{7 1 4 , 3 6 6 . 0 0}$ & $\mathbf{7 7 4 , 6 8 4 . 2 0}$ & $\mathbf{7 7 3 , 5 9 9 . 0 0}$ \\
India & $299,389.60$ & $367,031.00$ & $477,947.00$ & $491,659.90$ & $477,213.00$ \\
China & ---- & $62,451.00$ & $73,319.00$ & $100,166.00$ & $115,694.00$ \\
Other Countries & $162,278.10$ & $127,258.00$ & $163,100.00$ & $182,862.00$ & $180,692.00$ \\
\hline
\end{tabular}

Source - Economic Survey 2016/17

\subsection{Computation of Concentration Indices}

Following Hirschman (1945) and Poudyal (1988) in Nepalese context, the present study also computed the commodity and geographic concentration index of export and imports by calculating Gini-Hisrchman Coefficient of Concentration for the period from 1974/75 to 2005/06. Thus the present study calculates the concentration coefficients as follows. 


$$
\begin{aligned}
C_{x t} & =100 \times \sqrt{\sum_{i=1}^{n}\left(\frac{X_{i t}}{X_{t}}\right)^{2}} \\
\text { Or, } \quad C_{x t} & =100 \times \sqrt{\sum_{i=1}^{22}\left(\frac{X_{i t}}{X_{t}}\right)^{2}}
\end{aligned}
$$

Where, $\mathrm{i}=1,2,3$ year and $\mathrm{n}=$ number of year

$$
\begin{aligned}
& \mathrm{C}_{\mathrm{xt}}=\text { Concentration Coefficient for exports in Year } \mathrm{t} \\
& \mathrm{X}_{\mathrm{it}}=\text { Value of exports of commodity group in Year } \mathrm{t} \\
& \mathrm{X}_{\mathrm{t}}=\text { Total export in year } \mathrm{t}
\end{aligned}
$$

The coefficient for imports is also defined in the same way.

$$
\begin{aligned}
& \text { Cit }=100 \times \sqrt{\sum_{i=1}^{n}\left(\frac{I_{i t}}{I_{t}}\right)^{2}} \\
& C_{i t}=\text { Concentration Coefficient for import in Year } \mathrm{t} \\
& I_{i t}=\text { Value of Import of commodity group in year } \mathrm{t} \\
& I_{t}=\text { Total import in year } \mathrm{t}
\end{aligned}
$$

The concentration coefficient of exports and imports with overseas countries and India were calculated separately. On the basis of concentration, a general observation can be drawn that higher the level of concentration, there is a higher possibility of decline in exports. Similarly, higher concentration on imports from a particular country (say India) means lower level of diversification of import from other countries. In other words, concentration and diversification have a kind of inverse relation.

On the other hand, the geographic concentration of exports and imports denotes that which country/geographic region has higher degree of concentration. This index depicts the relations of concentration on export and import and may suggest the possible measures and put forward reasons as why export/import are concentrated on particular country.

$$
G_{x t}=100 \times \sqrt{\sum_{i=1}^{n}\left(\frac{X_{i t}}{X_{t}}\right)^{2}}
$$

Where, $\mathrm{i}=1,2,3$ years and $\mathrm{n}=$ number of years.

$$
\begin{aligned}
& \mathrm{G}_{\mathrm{xt}}=\text { Index of Geographic Concentration in year } \mathrm{t} \\
& \mathrm{X}_{\mathrm{it}}=\text { Value of exports with country I in year } \mathrm{t} \\
& \mathrm{X}_{\mathrm{t}}=\text { Total exports in year } \mathrm{t}
\end{aligned}
$$


The formula for geographic concentration of import is the same as that for exports given above. In this case also the highest possible value of index is also 100 when a country's trade is completely monopolized by another single particular country. The lower limit of the index is $\frac{100}{\sqrt{n}}$ where; $\mathrm{n}$ is the number of trading partners. At the extreme, the value may approximate to zero when an infinite number of countries each possesses an infinitesimally small share in the trade of the country.

\subsection{Measuring Impact of Policy Changes}

The regression model specified for measuring impact of policy changes involved the equation of economic development as a dependent variable and export as independent variable. GDP was considered as the proxy variable of economic development. The time series data included in the model constituted from 1974/75 to 2016/17.

The regression of the whole and sub-periods facilitates to measure the impact of policy changes.

Symbolically, the regression function is expressed as:

$$
(\mathrm{RGDP})_{\mathrm{t}}=\beta_{0}+\beta_{1}(\mathrm{REx})_{\mathrm{t}}+\ldots \ldots \ldots \ldots \mathrm{U}_{\mathrm{t}} \ldots \ldots \text { (I) }
$$

Where,

$$
\begin{array}{ll}
\text { RGDP } & - \text { represents for Real Gross Domestic Product at time t } \\
\text { REx } & - \text { represents for Real Export at time ' } t \text { ' and } \\
U_{t} & - \text { represents for Disturbance term }
\end{array}
$$

In log linear form-

$$
\operatorname{Ln}(\text { RGDP })_{\mathrm{t}}==\beta_{0+} \log (\mathrm{REx})_{\mathrm{t}}+\ldots \ldots \ldots \ldots \ldots \mathrm{U}_{\mathrm{t}} \ldots \ldots(\mathrm{I})
$$

The impact of policy changes was measured using the Chow Test. In order to undertake the Chow test the data series were divided into two groups- one consisting the period between $1974 / 75$ to $1989 / 90$ and another series of data that consisted data after 1990/91.

The Chow Test (named after Gregory Chow - 1960, who first popularized it) has been used to test whether there has been a structural change at time $t=n_{1}$. The procedure is to divide the sample of $n$ observation into two periods - Period -1 consisting of the first $n_{1}$ observations and Period- 2 consisting of the remaining $n_{2}=n-n_{1}$ observations. Estimate the model (with $\mathrm{k}$ regression coefficients) separately for each of the two sample periods and compute the sum of squared residuals $\mathrm{ESS}_{1}$ and $\mathrm{ESS}_{2}$.

Similarly a regression is run for whole period beginning from $\mathbf{n}_{1}$ to the end of $\mathbf{n}_{2}$. The errors sum of squares is estimated for all three different periods. The sum of errors of regression of two groups is considered as unrestricted $\mathrm{ESS}_{\mathrm{UR}}$, while the ESS of whole group is considered as $\mathrm{ESS}_{\mathrm{R}}$ which is taken as restrictive $\mathrm{ESS}_{\mathrm{R}}$ This carries a chi-square distribution with d.f $\left(\mathrm{n}_{1}-\mathrm{k}\right)+\left(\mathrm{n}_{2}-\mathrm{k}\right)=\mathrm{n}-2 \mathrm{k}$ because estimation of the model separately implies that each equation has $\mathrm{k}$ regression coefficients.

Next assume that the regression coefficients are the same before and after period $n_{1}$ (which gives rise to $\mathrm{k}$ restrictions). Estimate the model again, but with the pooled sample and obtain 
$\mathrm{ESS}_{\mathrm{R}}$. The appropriate test statistic is now-

$$
F_{C}=\frac{E_{R}-\left(E_{1} S_{1}-E S S_{2}\right) \div \mathrm{k}}{\left(E_{1}+E_{1}\right) \div\left(n_{1}+n_{2}-2 k\right)}
$$

Where, $\mathrm{ESS}_{\mathrm{R}}=$ estimated sum of squares (residuals)/ $\mathrm{ESS}_{1}=$ estimated sum of square for the first period and $\mathrm{ESS}_{2}=$ estimated sum of square for the second period, $\mathrm{F}_{\mathrm{c}}=\mathrm{F}$ distribution, $\mathrm{n}_{1}=$ number of observation for the first period and $\mathrm{n}_{2}$ number of observation for the second period and $\mathbf{k}=$ regression.

The test procedure is to reject the null hypothesis that there is no structural change if $F_{c}$ exceeds $\mathbf{F}_{\mathbf{k}}, \mathbf{n}_{-2 \mathbf{k}}$, the point on the $\mathrm{F}$ distribution with $\mathrm{k}$ and $\mathrm{n}-2 \mathrm{k} d . f$ such that the area to the right is equal to the level of significance. An important assumption behind this test is that the error variances of the two samples are the same.

\section{Conclusion}

The overall trend of Nepal's export trade has been undergoing through lots of turbidity owing to change in the policy with the change of government. Political instability can be blamed as one of the key reasons for policy volatility that have caused turbulence in Nepal's export trade.

If we look at the percentage of change in the volume of both export and import trade with India and abroad, changes in export and import in the years of eighties, nineties can be witnessed as the country had passed through lots of political instability and changes in the government. Table -2 which shows the direction of Foreign Trade depicts that export with other countries in comparison to India and China had suffered particularly in the early decades of 1990 s and 2000. Apart from policy, there are number of factors like connectivity, governance, technical support and economic diplomacy which play a significant role in expanding trade diversification. Definitely government policy (trade policy, monetary policy, interest rate policy, tax policy) has major role in determining trade diversification. Nonetheless, supporting factors like connectivity, distance, technology and trade governance equally play a dominant role in smoothen trade diversification.

\section{References}

Adhikari, D. (2018). Impact of exchange rate on trade deficit and foreign exchange reserve in Nepal: An empirical analysis. NRB Economic Review, 35-48.

Acharya, K. (2019). Nepalese foreign trade: Growth, composition, and direction. NCC Journal, 4 (1), 91-96.

Bajracharya, P., Manandhar, M. D., \& Bajracharya, R. (2019). Nepal's economy in disrray. New Delhi: Adroit Publishers.

NJMSR V. 3 Issue 2(2019) 137 
Export Diversification of Nepal: Policy Context and Impacts

Dutta, P Mihov, \& Zandt (2008). Retrieved from https://faculty.insead.edu/pushan-dutt/ documents/diversification.pdf dated September 15, 2019

Huang, \& David. (1989). Tariff structure and trade in Canada ITO. Retrieved from www. naftatradestrucutre.com/html/0412/et194 dated October 17, 2007.

McAllister. (2004). Nepal's king caves into opposition. Time Magazine, USA: Time International Group. Retrieved from www.outlookindia.com > Magazine > International dated April 21,2004,16.

Pant, B. (2005). Nepal's trade sector: Review, repercussions and recommendations. Nepal Economic Review, 45-89.

Pant, B. (2015). Nepal's trade sector: review, repercussions and recommendations. The Economic Review, Occasional Paper, 17, Kathmandu: Nepal Rastra Bank.

Poudyal, S. R. (1988). Foreign trade aid and development in Nepal ( $1^{\text {st }}$ ed.). New Delhi: Commonwealth Publishers.

Poudyal, S. R. (1998). Causes of export instability in Nepal. Kathmandu: Quarterly Economic Bulletin, NRB.

Regmi, U. (2010) Administration and management. Review, 22(1).

Sharma, G. (1999). Nepal missing elements in development thinking. New Delhi: Nirala Publications.

Sthapit, A. (2017). International business: Text and cases (5 ${ }^{\text {th }}$ ed.). Kathmandu: Taleju Prakashan, Publisher and Distributor.

\section{Official Websites}

http://www.nrb.org.np (Nepal Rastra Bank)

www.adb.org/nrm (Asian Development Bank - Nepal Country

www.fncci.org.np (Federation of Nepalese Chambers of Commerce and Industry)

www.ganasso.com (Garment Association Nepal)

www.mof.gov.np (Ministry of Finance)

www.moics.gov.np (Ministry of Industry Commerce and Supplies)

www.nepaleseeconomy.com via www.wb.com (World Bank)

www.npc.gov.np (National Planning Commission)

www.saarc.net.com (South Asian Association of Regional Cooperation)

www.tepc.org.np (Trade and Export Promotion Center Nepal) 